\author{
ELIZA MAZURCZAK-JASIŃSKA \\ ORCID: 0000-0003-2412-2427 \\ Uniwersytet Wrocławski
}

\title{
SĄD WŁAŚCIWY W SPRAWACH O ROSZCZENIA ZE STOSUNKÓW SŁUŻBOWYCH SĘDZIÓW I PROKURATORÓW — WYBRANE ZAGADNIENIA (PRZYCZYNEK DO DYSKUSJI)
}

\begin{abstract}
Abstrakt: Artykuł poddaje analizie zagadnienie sądu właściwego w zakresie ochrony roszczeń wynikających ze stosunków zatrudnienia sędziów i prokuratorów. W nominacyjnych stosunkach pracy tych podmiotów elementy publicznoprawne istotnie przeważają nad pracowniczymi. Autorka podejmuje próbę zdefiniowania pojęcia sprawy o roszczenia wynikające ze stosunków służbowych tego rodzaju. Celem opracowania jest wykazanie, na podstawie wybranych przykładów wynikających z obecnie obowiązujących regulacji, że ustawodawca nie dostrzega złożoności i specyfiki pracowniczego zatrudnienia służbowego, co ma negatywne implikacje w zakresie realizacji konstytucyjnej zasady prawa do sądu.
\end{abstract}

Słowa kluczowe: sędzia, prokurator, mianowanie, stosunek służbowy, Prezydent RP, Prokurator Generalny

\section{WPROWADZENIE}

Najistotniejsze elementy składające się na status prokuratorów powszechnych jednostek prokuratury uregulowane są obecnie w ustawie z dnia 28 stycznia 2016 roku — Prawo o prokuraturze (dalej: prawo o prok.). Wybrane elementy statusu prawnego sędziów unormowane zostały natomiast $\mathrm{w}$ akcie prawnym najwyższego rzędu, jakim jest Konstytucja $\mathrm{RP}^{1}$. Komplementarne dla przepisów ustawy zasadniczej, w zakresie elementów kształtujących status tych podmiotów, są przepisy ustawy z 27 lipca 2001 roku — Prawo o ustroju sądów powszechnych ${ }^{2}$ (dalej: p.u.s.p.). Pozycja ustrojowa sędziów, ze względu na przysługującą im kompetencję jurysdykcyjną, a także usytuowanie sądów jako organów wymiaru sprawiedli-

1 S. Dąbrowski, A. Łazarska, [w:] Prawo o ustroju sądów powszechnych. Komentarz, red. A. Górski, LEX 2013, komentarz do art. 55, nota 2.

2 Tekst jedn. Dz.U. z 2020 r. poz. 2072 ze zm. 
wości względem organów władzy ustawodawczej i wykonawczej, może powodować wątpliwości co do zasadności prowadzenia łącznej analizy sytuacji prawnej sędziów i prokuratorów pod kątem właściwości sądów w sprawach roszczeń wynikających z ich stosunków służbowych. Wskazać jednak należy, że w nauce prawa pracy nominacyjne stosunki zatrudnienia tych podmiotów zakwalifikowane zostały do tej samej kategorii - stosunków służbowo-pracowniczych ${ }^{3}$ ze względu na fakt, że w regulacji statusu sędziów i prokuratorów elementy o charakterze publicznoprawym zdecydowanie przeważają nad składnikami swoistymi dla stosunku pracy.

\section{PRAWO DO SĄDU „WŁAŚCIWEGO”}

Rudyment próby zdefiniowania pojęcia „sądu właściwego dla spraw wynikających ze stosunków służbowych sędziów i prokuratorów" stanowić musi konstytucyjna gwarancja prawa do sądu uregulowana przede wszystkim w przepisie art. 45 ust. 1, zgodnie z którym „Każdy ma prawo do sprawiedliwego i jawnego rozpatrzenia sprawy bez nieuzasadnionej zwłoki przez właściwy, niezależny, bezstronny i niezawisły sąd"4. W nauce prawa konstytucyjnego, jak również w orzecznictwie Trybunału Konstytucyjnego, przyjmuje się, że na konstytucyjne prawo do sądu składają się w szczególności takie elementy, jak: 1. prawo dostępu do sądu, to jest prawo uruchomienia procedury przed sądem; 2. prawo do odpowiedniego ukształtowania procedury sądowej oraz 3. prawo do wyroku sądowego ${ }^{5}$. Najistotniejsze z punktu widzenia przedmiotu analizy niniejszego opracowania, określone w punkcie pierwszym prawo dostępu do sądu, oznacza prawo uruchomienia procedury przed sądem, czyli organem o określonej charakterystyce: właściwym, niezależnym, bezstronnym i niezawisłym ${ }^{6}$. Chcąc dokonać

3 Szerzej na temat kryteriów tego podziału T. Kuczyński, Właściwość sądu administracyjnego w sprawach stosunków służbowych, Wrocław 2000, s. 42-46. Do tej kategorii zalicza się również stosunki służbowe etatowych członków SKO.

${ }^{4}$ Dopełnienie podstawowej formuły prawa do sądu wynikającej z przepisu art. 45 ust. 1 Konstytucji RP stanowią dalsze regulacje ustawy zasadniczej, to jest art. 77 ust. 2 (zakaz zamykania drogi sądowej dla dochodzenia naruszonych wolności lub praw) i art. 78 Konstytucji RP (wzmacniający poręczenie instancyjności jako proceduralnej zasady postępowania sądowego i decyzyjnego).

5 Zob. między innymi: M. Wyrzykowski, Komentarz do art. 1 przepisów utrzymanych w mocy, [w:] Komentarz do Konstytucji Rzeczypospolitej Polskiej, red. L. Garlicki, Warszawa 1995-1998, s. 31; P. Tuleja, [w:] Konstytucja Rzeczypospolitej Polskiej. Komentarz, red. P. Tuleja, Warszawa 2019, komentarz do art. 45. Zob. także wyroki Trybunału Konstytucyjnego z dnia: 9 czerwca 1998 roku, K 28/97, OTK 1998, nr 4, poz. 50; 16 marca 1999 roku, SK 19/98, OTK ZU 1999, nr 3, poz. 36; 10 maja 2000 roku, K 21/99, OTK 2000, nr 4, poz. 109; 24 października 2007 roku; OTK ZU 2007, nr 9/A, poz. 108; 27 maja 2008 roku, SK 57/06, OTK-A 2008, nr 4, poz. 63.

6 Wszystkie elementy są równie istotne, przy czym z punktu widzenia przedmiotu niniejszego opracowania najistotniejszy jest pierwszy z wymienionych. 
ustaleń co do właściwości danego sądu do rozpatrzenia konkretnej sprawy, nie można opierać się wyłącznie na unormowaniach ustawy zasadniczej ${ }^{7}$. Przepis art. 176 ust. 2 Konstytucji RP odsyła bowiem w tym zakresie do „ustaw”, przez które należy rozumieć przepisy prawa materialnego (przedmiot i rodzaj ochrony) oraz unormowania realizujących je przepisów procesowych (właściwość miejscowa i rzeczowa $)^{8}$. W poszczególnych gałęziach prawa pojęcie właściwości rozumiane jest jako zdolność prawna organu do rozpoznawania i rozstrzygania określonego rodzaju spraw w konkretnym postępowaniu ${ }^{9}$. W nauce przyjmuje się, że konstytucyjne określenie „właściwy sąd” może być łączone z trojakim rozumieniem tej właściwości ${ }^{10}$. Po pierwsze, pojęcie to oznacza sąd, który według regulacji procesowych jest $\mathrm{w}$ danej sprawie rzeczowo, miejscowo i funkcjonalnie właściwy ${ }^{11}$. Po drugie, sąd orzekający we właściwym składzie (określonym przede wszystkim przez przepisy proceduralne i ustrojowe) ${ }^{12}$. Po trzecie — określenie „właściwy sąd" łączone może być z ogólną właściwością sądów danego pionu do rozpoznawania danego rodzaju spraw, co w prawie cywilnym określane jest mianem drogi sądowej i z konstytucyjnego punktu widzenia to właśnie tak określona właściwość przedmiotowa jest najistotniejszym składnikiem tego konstytucyjnego pojęcia ${ }^{13}$.

Podkreśla się, że choć z przepisu art. 176 ust. 2 Konstytucji RP wynika, że ustrój, właściwość sądów i postępowanie przed tym organami określa ustawa, ustawodawca nie ma w tym obszarze pełnej swobody, gdyż niektóre kwestie $\mathrm{z}$ tego zakresu zostały przesądzone w samej ustawie zasadniczej ${ }^{14}$. Zgodnie $\mathrm{z}$ domniemaniem ustanowionym przez ustawodawcę w przepisie art. 177 Konstytucji RP sądy powszechne sprawują wymiar sprawiedliwości we wszystkich sprawach, z wyjątkiem tych ustawowo zastrzeżonych dla właściwości innych sądów. Jego konsekwencją jest to, że w przeciwieństwie do właściwości innych rodzajów sądów kompetencja sądu powszechnego do rozpoznania sprawy nie musi wynikać z wyraźnej dyspozycji ustawowej i wystarczające jest ustalenie, że ustawa nie przekazuje określonej kategorii spraw do rozpoznania innym sądom lub organom ${ }^{15}$. Implikacją domniemania ustanowionego w art. 177 Konstytucji RP jest również to, że milczenia ustawodawcy (w kwestii właściwości sądu) nie można traktować jako równoznacznego z zamknięciem drogi sądowej w danej spra-

7 A. Kubiak, Konstytucyjna zasada prawa do sądu w świetle orzecznictwa Trybunatu Konstytucyjnego, Łódź 2006, s. 125.

8 Ibidem, s. 125; Z. Czeszejko-Sochacki, Prawo do sadu w'świetle Konstytucji Rzeczypospolitej Polskiej (ogólna charakterystyka), „Państwo i Prawo” 1997, nr 11-12, s. 97.

9 A. Kubiak, op. cit., s. 124 i przywołana tam literatura.

10 W. Sanetra, Sąd właściwy w rozumieniu Konstytucji RP, „Przegląd Sądowy” 2011, nr 9, s. 11.

11 Ibidem.

12 Ibidem.

13 Ibidem, s. 11-14.

14 Ibidem, s. 14.

15 Por. postanowienie Sądu Najwyższego z dnia 8 lipca 2015 roku, I PK 250/14, OSNP 2017, nr 5, poz. 56 . 
$w_{i e^{16}}$. Zasada domniemania kompetencji sądów powszechnych powinna znaleźć zastosowanie zawsze wtedy, gdy ustawa nie reguluje właściwości sądu bądź też — z uwagi na niejednorodny charakter jurydyczny danej sprawy — nie sposób zakwalifikować jej do właściwości jakiegokolwiek sądu ${ }^{17}$. Zakres spraw przekazanych właściwości sądownictwa administracyjnego określony został w przepisie art. 184 ustawy zasadniczej, zgodnie z którym Naczelny Sąd Administracyjny oraz inne sądy administracyjne sprawują, w zakresie określonym w ustawie, kontrolę działalności administracji publicznej. Kontrola ta obejmuje również orzekanie o zgodności z ustawami uchwał organów samorządu terytorialnego i aktów normatywnych terenowych organów administracji rządowej. Ustalenie, przy orzekaniu o swej właściwości przez sąd administracyjny, że sprawa obejmuje kontrolę działalności administracji publicznej (art. 184 Konstytucji RP w związku z art. 1 p.p.s.a.), powoduje uchylenie domniemania wynikającego $z$ art. 177 Konstytucji RP i zwalnia sąd powszechny z obowiązku rozpatrzenia sprawy ${ }^{18}$. Sąd Najwyższy powołany jest do sprawowania nadzoru nad działalnością sądów powszechnych i wojskowych w zakresie orzekania oraz wykonywania innych czynności określonych w Konstytucji i ustawach (art. 183 ust. 1 i 2 Konstytucji RP) ${ }^{19}$.

\section{SPRAWA O ROSZCZENIA ZE STOSUNKU SŁUŻBOWEGO}

W związku z regulacją art. 76 k.p. nie wzbudza wątpliwości, że podmioty zatrudnione na skutek dokonania aktu mianowania są pracownikami, a ich status regulowany jest przede wszystkim przepisami pragmatyk służbowych, natomiast kodeks pracy znajdzie do nich zastosowanie jedynie w zakresie w nich nieuregulowanym (art. 5 k.p.). Dla natury pracowniczych stosunków służbowych nie pozostał jednak obojętny fakt, że wywodzą się one z tradycyjnego stosunku służbowego o charakterze wyłącznie publicznoprawnym. Ponadto podmioty w nich pozostające pełnią różnego rodzaju funkcje w sferze państwowej (publicznej). $Z$ tych też względów pracownicze pragmatyki służbowe różni w znaczny sposób zakres nasycenia stosunkami należącymi do zakresu prawa pracy i prawa administracyjnego statusu podmiotów, których te regulacje dotyczą, oraz wzajemny rozkład pierwiastków „pracowniczych” i ,służbowych” w strukturze złożonego stosunku prawne-

16 B. Naleziński, [w:] Konstytucja Rzeczypospolitej Polskiej. Komentarz, red. P. Tuleja, komentarz do art. 177 nota 2 oraz cytowane tam orzecznictwo.

17 A. Kubiak, op. cit., s. 126.

18 M. Masternak-Kubiak, [w:] Konstytucja Rzeczypospolitej Polskiej. Komentarz, red. M. Haczkowska, Warszawa 2014, komentarz do art. 177 nota 2; B. Naleziński, op. cit., komentarz do art. 184 nota 2 .

19 Zob. też art. 1 ustawy z dnia 8 grudnia 2017 roku o Sądzie Najwyższym (tekst jedn. Dz.U. z 2021 r. poz. 154). 
go, w jakim pozostają ${ }^{20}$. Jak wspomniano we wstępie, stosunki służbowe sędziów i prokuratorów zalicza się do kategorii służbowo-pracowniczych.

Stosunek służbowy sędziego jest szczególnym stosunekiem prawnym łączącym sędziego z państwem i pracodawcą, obejmującym elementy o charakterze publicznoprawnym (na przykład moc wydawania wyroków w imieniu państwa), korporacyjnym (przynależność do samorządu sędziowskiego oraz prawo i obowiązek wykonywania jego zadań), a także czysto pracowniczym (prawa i obowiązki pracownicze, na przykład prawo do uzyskania wynagrodzenia, urlopu wypoczynkowego, ale także obowiązek dochowania tajemnicy). Podobnie jak w przypadku sędziów w regulacji statusu prawnego prokuratorów dostrzegalne jest wyraźne normatywne rozgraniczenie stanowiska prokuratora jako organu egzekucyjnego w zakresie praworządności wyrastającego ze stosunku publicznoprawnego łączącego go z państwem powierzającym mu władzę prokuratorską od pozycji pracownika pozostającego $\mathrm{w}$ stosunku pracy ${ }^{21}$.

Przechodząc do kwestii procesowych, wskazać należy, że przez sprawy o roszczenia ze stosunku pracy należy rozumieć takie sprawy, w których roszczenie powoda (pracownika lub pracodawcy) ma swoje materialne źródło w treści stosunku pracy bez względu na to, na jakiej podstawie stosunek ten został nawiązany (umowa o pracę, powołanie, mianowanie, wybór czy spółdzielcza umowa o pracę) $)^{22}$. Podstawą powództwa jest w tym przypadku niewykonanie lub nienależyte wykonanie obowiązku wynikającego z umowy o pracę lub przepisów prawa pracy ${ }^{23}$ przez jedną ze stron stosunku pracy (art. $476 \S 1$ k.p.c.) ${ }^{24}$.

$\mathrm{Na}$ gruncie przepisów prawa i postępowania administracyjnego odpowiednikiem roszczenia ze stosunku pracy jest roszczenie administracyjnoprawne, to jest prawo podmiotu do żądania wydania przez organ administracji aktu (podjęcia działania) administracyjnego określonej treści, którego normatywne podstawy ulokowane są w prawie publicznym. W przeciwieństwie do przepisów procedury cywilnej regulacje procedury administracyjnej nie zawierają definicji legalnej sprawy administracyjnej, co może budzić wątpliwości co do zakresu tego pojęcia i rodzi konieczność wypełnienia tej luki przez doktrynę i orzecznictwo ${ }^{25}$. Sprawą administracyjną byłaby zatem: możliwość realizacji w sposób autorytatywny,

20 Por. T. Kuczyński, op. cit., s. 42.

21 Ibidem, s. 43.

22 A. Rycak, [w:] Kodeks pracy. Komentarz, red. K. Walczak, Legalis 2020, komentarz do art. 262 .

${ }^{23}$ Pod pojęciem przepisów prawa pracy należy rozumieć również układy zbiorowe pracy $\mathrm{i}$ inne regulacje zakładowe.

24 Zob. uchwałę Sądu Najwyższego z 17 lipca 1987 roku, III PZP 27/87, OSNCP 1988, nr 10, poz. 140 .

25 Por. P. Szustakiewicz, Stosunki stużbowe funkcjonariuszy stużb mundurowych $i$ żotnierzy zawodowych jako sprawa administracyjna, Warszawa 2012, s. 54; A. Wilczyńska, Sprawa z zakresu administracji publicznej na tle pojęć sprawy administracyjnej i sprawy cywilnej - zagadnienia teoretycznoprawne, „Zeszyty Naukowe Sądownictwa Administracyjnego” 4, 2008, nr 5, s. 74. 
określony przez przepisy postępowania administracyjnego, praw lub obowiązków wynikających ze stosunku administracyjnoprawnego, opartego na przepisach prawa administracyjnego materialnego, w odniesieniu do ściśle określonego podmiotu niebędącego organem administracji publicznej ${ }^{26}$. W momencie złożenia przez podmiot administrowany żądania wszczęcia postępowania bądź też $\mathrm{w}$ razie wszczęcia postępowania z urzędu przez podmiot administrujący, sprawa administracyjna staje się przedmiotem postępowania jurysdykcyjnego ${ }^{27}$. Rozstrzygnięciem sprawy administracyjnej, czyli autorytatywnym ustaleniem przez podmiot administrujący, że abstrakcyjna norma prawna znajduje zastosowanie w danym stanie faktycznym, jest decyzja administracyjna ${ }^{28}$. Na płaszczyźnie formalnej, w ujęciu ustawowym, sprawą sądowoadministracyjną jest każda sprawa z zakresu kontroli działalności administracji publicznej lub każda inna sprawa, do której stosuje się przepisy prawa o postępowaniu przed sądami administracyjnymi (art. 1 p.p.s.a. ${ }^{29}$. W ujęciu materialnym natomiast sprawa sądowoadministracyjna jest tą samą, która zaistniała wcześniej w postępowaniu administracyjnym zakończonym decyzją zaskarżoną do sądu albo która istniała w trakcie przygotowania innego aktu podlegającego zaskarżeniu ${ }^{30}$. Sąd administracyjny rozpoznaje zatem tę samą „sprawę", mając wobec niej, co do zasady, inne zadania do spełnienia niż organ ją wydający — nie określa niczyich praw lub obowiązków z niej wynikających, ale jedynie kontroluje ich określenie ${ }^{31}$.

$\mathrm{Na}$ gruncie regulacji pragmatyki prokuratorskiej przyjęto, że w sprawach o roszczenia ze stosunku służbowego prokuratorowi przysługuje droga postępowania przed sądem właściwym dla spraw pracowniczych (art. $101 \S 1$ prawo o prok.). W ustawie Prawo o ustroju sądów powszechnych ustawodawca nie zdecydował się na przyjęcie podobnego rozwiązania. W sposób wyraźny wskazano jedynie sąd właściwy w zakresie kontroli wybranych decyzji wydanych w sprawie przeniesienia sędziego na inne miejsce służbowe. Tymczasem przyjęte konstrukcje prawne, w szczególności te związane z nawiązaniem i zmianą stosunków służbowych, są w obydwu ustawach bardzo podobne. Biorąc jednak pod uwagę przeprowadzone wyżej rozważania definicyjne dotyczące przede wszystkim pojęcia sprawy o roszczenia ze stosunku pracy i sprawy sądowoadministracyjnej, zastanowienia wymaga kwestia, czy praktyka ustawodawcy polegająca na przekazywaniu wszystkich spraw o roszczenia ze stosunku służbowego na drogę postępowania przed sądem pracy jest właściwa. Niewątpliwie natomiast ze względu na

26 Ibidem, s. 54-59.

27 A. Wilczyńska, op. cit., s. 75.

28 Ibidem.

29 J. Zimmermann, $Z$ podstawowych zagadnień sadownictwa administracyjnego, [w:] Sądownictwo administracyjne gwarantem wolności i praw obywatelskich 1980-2005, red. J. Góral, R. Hauser, J. Trzciński, Warszawa 2005, s. 496.

30 Ibidem.

31 Ibidem. 
konstytucyjną regulację prawa do sądu, brak wyraźnego wskazania kompetencji w zakresie kontroli czynności dotyczących poszczególnych elementów statusu sędziów nie pozwala na przyjęcie założenia o pozbawieniu ich sądowej ochrony w zakresie roszczeń wynikających z ich stosunków służbowych.

Na skutek dokonanego przez ustawodawcę podmiotowego i rzeczowego rozdzielenia kompetencji pomiędzy podmiotem zatrudniającym sędziów i prokuratorów a organem dokonującym ich nominacji, zmiany stosunku prawnego i rozwiązania stosunku służbowego ${ }^{32}$, najistotniejsze czynności w zakresie statusu tych podmiotów przekazane zostały Prezydentowi RP ${ }^{33}$, Ministrowi Sprawiedliwości oraz Prokuratorowi Generalnemu ${ }^{34}$. Pozycja ustrojowa, charakter i interes prawny przedsiębranych przez nich czynności w zakresie stosunków służbowych sędziów i prokuratorów nie mogą pozostać bez wpływu na sposób konstruowania definicji sprawy o roszczenie ze stosunku służbowego. Oznaczałoby to bowiem całkowite pominięcie elementów publicznoprawnych występujących w złożonej strukturze stosunków służbowych sędziów i prokuratorów oraz skoncentrowanie się wyłącznie na tym, że podmioty te są pracownikami w rozumieniu regulacji art. 2 k.p. Takie ukształtowanie statusu sędziowskiego i prokuratorskiego uniemożliwia jednorodną ocenę charakteru spraw z nich wynikających.

\section{SPRAWY O ROSZCZENIA ZE STOSUNKÓW SŁUŻBOWYCH SĘDZIÓW I PROKURATORÓW — WYBRANE ZAGADNIENIA}

Analizując wybrane regulacje pragmatyk służbowych w kontekście problematyki będącej przedmiotem rozważań niniejszego opracowania, w aspekcie kolejnych etapów trwania stosunków służbowych sędziów i prokuratorów, rozważania rozpocząć należy od wątpliwości występujących na tle prezydenckiego aktu powołania do pełnienia urzędu na stanowisku sędziowskim. Uwagę zwraca występująca zarówno w orzecznictwie, jak i w piśmiennictwie istotna rozbieżność poglądów w kwestii oceny samego charakteru prawnego prezydenckiego umocowania, co implikuje dalsze wątpliwości w zakresie dopuszczalności sądowej ochrony roszczeń podmiotu, któremu Prezydent RP odmówił nominacji. Przyjęte, nie tylko przez sądy administracyjne, ale także przez niektórych przedstawicieli nauki, stanowisko wskazujące na ustrojowy charakter umocowania Prezydenta,

32 Zastrzec jednak należy, że do ustania służbowego stosunku pracy sędziego dochodzi tylko W wyniku jego rozwiązania z mocy prawa lub wygaśnięcia. W związku z tym brakuje podmiotu uprawnionego w imieniu pracodawcy do złożenia oświadczenia woli, w wyniku którego dojdzie do rozwiązania z sędzią tego stosunku.

33 Rola Prezydenta RP związana jest tylko z jedną, aczkolwiek bardzo doniosłą czynnością powołaniem sędziów do pełnienia urzędu na stanowisku sędziowskim.

$34 \mathrm{~W}$ niektórych sprawach dotyczących statusu prokuratorów kompetencje przysługują również Prokuratorowi Krajowemu. 
negujące możliwość kwalifikacji materii powoływania sędziów do materialnego prawa administracyjnego, co w konsekwencji oznacza brak możliwości zakwalifikowania aktu nominacyjnego jako decyzji czy też aktu lub czynności z art. 3 $\S 2$ pkt 1 p.p.s.a. ${ }^{35}$, wzbudza wątpliwości. W opozycji do wskazanego zapatrywania pozostają stanowiska przedstawicieli doktryny wskazujące na zobowiązujący charakter normy zawartej w przepisie art. $55 \S 1$ p.u.s.p., wynikający ze zwrotu „powołuje”, co oznaczać ma, że organ ten nie ma możliwości odstąpienia od obowiązku realizacji tego zadania ${ }^{36}$. Ponadto podnosi się, że z procesowego punktu widzenia kompetencja Prezydenta stanowi typowy przykład rozstrzygnięcia organu administracji publicznej, zewnętrznego i władczego, w ramach którego decyduje się o prawach publicznoprawnych (tu o prawie do wykonywania zawodu sędziego) konkretnych osób fizycznych w sprawie indywidualnej. Jest to więc czynność materialno-techniczna w przypadku powołania, a w przypadku odmowy powołania na stanowisko sędziego - czynność wywołująca skutek identyczny do decyzji administracyjnej, która powinna być dokonana na odpowiednio stosowanych zasadach określonych w k.p.a. ${ }^{37} \mathrm{~W}$ kontekście stanowisk przedstawicieli nauki, a także uwzględniając fakt, że analizowana problematyka dotyczy kolizji między wynikającą przede wszystkim z norm konstytucyjnych prezydencką prerogatywą a regulacjami konstytucyjnymi odnoszącymi się do dóbr i wartości wynikających z zasady demokratycznego państwa prawnego, do których należy prawo do sądu, a także stanowiące konkretyzację zasady równości wobec prawa oraz zasady wolności pracy (art. 65 ust. 1-3 Konstytucji) prawo dostępu do służby publicznej na jednakowych zasadach (art. 60 Konstytucji), rozważyć należałoby możliwość dokonania weryfikacji orzecznictwa sądów administracyjnych w zakresie oceny kompetencji desygnacyjnej Prezydenta RP. Przyjęta w nauce koncepcja sądu administracyjnego jako właściwego do kontroli aktu desygnacyjnego zasługuje na aprobatę.

Następnym z wybranych na potrzeby niniejszego opracowania zagadnień jest kwestia oceny charakteru prawnego stwierdzenia Ministra Sprawiedliwości (sędziowie — por. art. $65 \S 2$ i 33 p.u.s.p.) lub Prokuratora Generalnego (prokuratorzy — por. art. $91 \S 3$ ustawy prawo o prok.) ${ }^{38}$ wygaśnięcia powołania na skutek nieobjęcia pierwszego stanowiska sędziowskiego (prokuratorskiego) w ciągu czternastu dni od otrzymania aktu powołania. Słusznie wskazuje się, że analizowana czynność

35 Por. uzasadnienie postanowienia NSA z 9 października 2012 roku, I OSK 1874/12, LEX nr 1269629; a także P. Czarny, Realizacja konstytucyjnych kompetencji Prezydenta RP w odniesieniu do sadów i Krajowej Rady Sądownictwa, [w:] System rząów Rzeczypospolitej Polskiej. Założenia konstytucyjne a praktyka ustrojowa, red. M. Grzybowski, Warszawa 2006, s. 83; oraz A. Kijowski, Odrębność statusu prawnego sędziów Sądu Najwyższego, „Przegląd Sądowy” 2004, nr 1, s. 18.

36 R. Suwaj, Glosa do postanowienia WSA w Warszawie z dnia 23 stycznia 2008 r., I Sa/wa 2139/07, „Gdańskie Studia Prawnicze — Przegląd Orzecznictwa” 2009, nr 2, s. 26.

37 Ibidem.

${ }^{38}$ Na gruncie obecnie obowiązujących przepisów urząd Prokuratora Generalnego sprawuje Minister Sprawiedliwości (zob. art. 1 § 2 ustawy prawo o prok.). 
nie ma wyłącznie faktycznego charakteru i nie jest jurydycznie obojętna, ponieważ jest nośnikiem doniosłych treści prawnych ${ }^{39}$. Konsekwencją takiej oceny analizowanej czynności jest możliwość przyjęcia założenia o dopuszczalności poddania jej sądowej kontroli. Z regulacji pragmatyki prokuratorskiej wynika, że sądem właściwym w sprawach o roszczenia ze stosunku służbowego prokuratorowi przysługuje droga postępowania przed sądem właściwym dla spraw pracowniczych (art. 101 prawo o prok.), co może implikować twierdzenie, że kompetencje tego sądu rozciągają się również na ocenę prawidłowości analizowanej czynności Prokuratora Generalnego ${ }^{40}$. Wprawdzie w ustawie Prawo o ustroju sądów powszechnych nie ma podobnej regulacji, ale ze stanowiska doktryny wynika, że ze względu na tkwiące w stosunku służbowym elementy stosunku pracy „stwierdzenie” Ministra Sprawiedliwości zakwalifikować należy jako akt (oświadczenie) wiedzy w zakresie stosunku pracowniczego, w którym zawiera się ustalenie nieistnienia (niepowstania) stosunku pracy, który w razie sporu co do jego treści (zasadności) może być kwestionowany przed sądem pracy ${ }^{41}$. Tymczasem podkreślić należy, że mianowanie na stanowisko sędziego (prokuratora) ma na początku cechy aktu włączającego tylko do służby. Doręczenie aktu mianowania pierwotnie prowadzi wyłącznie do nawiązania stosunku służbowego z państwem, reprezentowanym przez Prezydenta RP (Prokuratora Generalnego), ale nie z nawiązaniem stosunku pracy. Nawiązanie stosunku pracy z sądem (prokuraturą), w którym sędziowie czy prokuratorzy mają pełnić swoją funkcję, następuje dopiero $\mathrm{z}$ chwilą objęcia stanowiska, co powinno nastąpić w ciągu czternastu dni od otrzymania aktu mianowania. Do chwili objęcia pierwszego stanowiska sędziowie i prokuratorzy pozostają wyłącznie w stosunku służby ${ }^{42}$. Relacja między organem dokonującym nominacji a mianowanym sędzią czy prokuratorem, który nie objął stanowiska, ma charakter wyłącznie publicznoprawny. De lege ferenda należałoby zatem rozważyć możliwość poddania tego rodzaju sprawy wynikającej z publicznoprawnego stosunku służbowego procesowym zasadom dotyczącym załatwiania spraw publicznych, a w konsekwencji kontroli sądu administracyjnego ${ }^{43}$.

Kolejne zagadnienie, które z procesowego punktu widzenia może wzbudzać istotne wątpliwości, to kwestia sądu właściwego w zakresie kontroli formalnie i materialnie jednostronnego aktu Prokuratora Generalnego ${ }^{44}$ przenoszącego na

39 T. Ereciński, J. Gudowski, J. Iwulski, Prawo o ustroju sąów powszechnych. Ustawa o Krajowej Radzie Sądownictwa. Komentarz, red. J. Gudowski, Warszawa 2009, komentarz do art. 55 , nota 2 .

40 Zob. też A. Kiełtyka, W. Kotowski, A. Ważny, Prawo o prokuraturze. Komentarz, Warszawa 2017, komentarz do art. 101, nota 1.

${ }^{41}$ T. Ereciński, J. Gudowski, J. Iwulski, op. cit., komentarz do art. 55, nota 2.

42 Por. T. Kuczyński, Glosa do uchwaly SN z 27 września 2002 r., III UZP 5/02, „Orzecznictwo Sądów Polskich” 2004, nr 9, s. 461.

43 Tak też T. Kuczyński, op. cit., s. 89.

44 Drugim z podmiotów właściwych do podejmowania formalnie i materialnie jednostronnych aktów przeniesienia na stałe lub czasowo delegujących prokuratora na inne miejsce służbowe jest Prokurator Krajowy. 
stałe lub czasowo delegującego prokuratora na inne miejsce służbowe (por. art. 94 $\S 2$ ustawy o prok., art. $106 \S 1-3^{45}$ ), a także podobnej czynności Ministra Sprawiedliwości przenoszącego na stałe sędziego na inne miejsce służbowe (por. art. 75 $\S 2-4$ p.u.s.p.).

Ze względu na dosłowne brzmienie powołanego już wcześniej przepisu art. $101 \S 1$ ustawy prawo o prok., uznać należy, że de lege lata właściwym do rozstrzygnięcia sprawy tego rodzaju jest sąd pracy. Warto jednak podkreślić, że kiedy podmiotem dokonującym przeniesienia jest organ usytuowany poza strukturą pracodawcy, będący organem nadrzędnym zarówno wobec jednostki zatrudniającej prokuratora, jak i tej, do której następuje przeniesienie, czynność ta wykracza poza schemat wzajemnego zobowiązania pracownika i pracodawcy (podobnie jak ma to miejsce w przypadku stwierdzenia utraty mocy powołania na stanowisko) ${ }^{46}$. Prokurator Generalny działa tu we własnym imieniu, w interesie publicznym, a nie indywidualnym zatrudnionego. Nie można zatem, wbrew temu, do czego zdaje się zmierzać orzecznictwo Sądu Najwyższego, a także niektórzy przedstawiciele doktryny ${ }^{47}$, przypisywać tej czynności charakteru wypowiedzenia zmieniającego dokonywanego przez podmiot zatrudniający pracownika. Ma ona bowiem charakter publicznoprawny i nosi znamiona decyzji administracyjnej. Choć rozstrzygnięcie jest podejmowane w ramach istniejącego stosunku służbowego, nie oznacza to, że wynikająca zeń sprawa nie mogłaby podlegać regulacjom procedury administracyjnej i sądowoadministracyjnej. Akt ten nie dotyczy bowiem sfery tak zwanej podległości służbowej wynikającej z zasady zwierzchnictwa w stosunkach między osobami piastującymi funkcje organów a pracownikami aparatu pomocniczego zajmującymi pozycję podwładnych w ramach wykonywania obowiązków służbowych. Jest ona konstrukcyjnym odpowiednikiem instytucji podporządkowania w prawie pracy, oznaczającej obowiązek wykonywania poleceń mieszczących się w treści powinności wynikających z aktu kreującego stosunek pracy (służby) ${ }^{48}$. Jest też przejawem charakterystycznej dla stosunków służbowych dyspozycyjności, oznaczającej obowiązek poddania się w granicach określonych przepisami prawa aktom zmieniającym lub istotnie modyfikującym dotychczasowy schemat (treść) stosunku służby lub pracy ${ }^{49}$. Konsekwentnie, z tych samych względów, walor aktu administracyjnego należałoby nadać rozstrzygnięciu Ministra Sprawiedliwości w sprawach związanych z przeniesieniem sędziego na stałe w inne miejsce służbowe. W pragmatyce sędziowskiej przyjęto jednak rozwiązanie, zgodnie z którym od decyzji Ministra Sprawiedliwości sędziemu przysługuje odwołanie

45 Delegowanie na okres nie dłuższy niż sześć lub dwanaście miesięcy w ciągu roku.

46 Por. T. Kuczyński, op. cit., s. 120.

47 Por. postanowienie Sądu Najwyższego z dnia 14 lipca 2016 roku, III PO 3/16, LEX $\mathrm{nr} 2142564$. Zob. też E. Baran, K.W. Baran, Droga sądowa z zakresu prawa pracy osób zatrudnionych w powszechnych jednostkach organizacyjnych prokuratury, „Prokuratura i Prawo” 1995, nr 6, s. 69.

48 T. Kuczyński, [w:] M. Masternak-Kubiak, T. Kuczyński, Prawo o ustroju sq̨dów administracyjnych. Komentarz, Warszawa 2009, s. 164 i cytowana tam literatura.

${ }^{49}$ Ibidem. 
do Sądu Najwyższego, przy czym, z niewiadomych względów, kontrolą tą nie objęto wszystkich przypadków przeniesienia (por. art. $75 \S 4$ p.u.s.p.). Choć ustawodawca $w$ stosunkach służbowych niejednokrotnie poddaje akty administracyjne związane ze zmianą lub ustaniem stosunku z nominacji kontroli sądów powszechnych (na przykład w przypadku urzędników służby cywilnej czy też kuratorów sądowych), powstaje pytanie, czy ze względu na wskazane wyżej argumenty, jak również regulacje ustawy zasadniczej (art. 177, art. 183 i art. 184 Konstytucji RP), taką praktykę należy w każdym przypadku uznać za właściwą.

Ostatnim z wybranych przykładów poddanych analizie jest zagadnienie związane z kompetencją notyfikacyjną Ministra Sprawiedliwości, w ramach której zawiadamia on sędziego o rozwiązaniu z mocy prawa lub wygaśnięciu stosunku służbowego (por. art. 72 p.u.s.p.). W pragmatyce sędziowskiej brakuje regulacji umożliwiającej wprost sądową kontrolę wskazanego aktu ministra. Zgodzić się należy z wyrażonym w nauce poglądem, że wskazane zawiadomienie ma charakter deklaratoryjny, potwierdzający jedynie wystąpienie skutków z mocy prawa ${ }^{50}$. Nie jest to jednak czynność jurydycznie obojętna. Jej charakter jest zbliżony bowiem do stwierdzenia przez Ministra Sprawiedliwości utraty mocy powołania na skutek nieusprawiedliwionego nieobjęcia pierwszego stanowiska sędziowskiego i również w tym przypadku nie można wykluczyć omyłki Ministra, która mogłaby zostać skorygowana na drodze sądowej. Uchybienia w tym zakresie mogłyby mieć charakter kompetencyjny (niewłaściwy organ), procesowy (błędny tryb) czy też materialny (niewłaściwa interpretacja przepisu). Zamknięcie sędziemu drogi sądowej w przypadku błędnej oceny zdarzeń skutkujących ustaniem lub przekształceniem służbowego stosunku pracy z mocy prawa, stawiałoby go w gorszej sytuacji niż pracownika, któremu na gruncie kodeksu pracy ustawodawca zagwarantował roszczenia w razie błędnej kwalifikacji zdarzenia, na mocy którego miałoby dojść do wygaśnięcia stosunku pracy przez pracodawcę (por. art. 67 k.p.). Przyjęcie przedstawionej interpretacji nie oznacza jednakże otwarcia sędziemu w tej sprawie drogi przed sądem pracy w celu kwestionowania wskazanego zawiadomienia. Przy uwzględnieniu publicznoprawnego charakteru stosunku łączącego sędziego z Ministrem Sprawiedliwości - organem znajdującym się poza strukturą pracodawcy - de lege ferenda należałoby również w tym przypadku rozważyć dopuszczalność kontroli tego aktu przez sąd administracyjny.

\section{PODSUMOWANIE}

Przedstawione przykłady nie wyczerpują oczywiście zagadnień, które mogą powstać na tle tytułowej problematyki. Z przedstawionych w opracowaniu przykładów wynika, że ustawodawca zdaje się nie dostrzegać złożoności i specyfiki pracowniczego zatrudnienia służbowego, a szczególnie tego o charakterze służ-

50 T. Ereciński, J. Gudowski, J. Iwulski, op. cit., komentarz do art. 72, nota 1. 
bowo-pracowniczym. Elementy pracownicze w takiej relacji mają względem publicznoprawnych jedynie instrumentalny, wykonawczy charakter. W konsekwencji pojawia się problem prawidłowej realizacji konstytucyjnego prawa do sądu przysługującego podmiotom, których status regulują pragmatyki służbowe. Przyjęta w ustawach koncepcja ochrony roszczeń sędziów i prokuratorów z pewnością wymaga weryfikacji. Rozważenia, chociażby w aspekcie treści przepisu art. 184 Konstytucji RP, wymaga przyjęta przez ustawodawcę praktyka poddawania kontroli sądów powszechnych aktów stanowiących w istocie decyzje administracyjne podejmowane w sprawach z zakresu administracji publicznej. Ewentualna korekta przyjętych w tym zakresie rozwiązań musi jednak uwzględniać fakt, że z nominacyjnym stosunkiem zatrudnienia wiążą się nie tylko — nieznane umownym stosunkom pracy — szczególne uprawnienia, ale również ograniczenia niektórych wolności i praw obywatelskich (w tym pracowniczych), na co dobrowolnie zgadzają się podmioty przyjmujące akt mianowania. Nie można zatem przyjąć, że takie ukształtowanie statusu sędziów czy też prokuratorów pozostaje zupełnie bez wpływu na zakres kontroli rozstrzygnięć dotyczących ich stosunków służbowych.

\section{JURISDICTION OVER CLAIMS ARISING OUT OF THE SERVICE RELATIONSHIPS OF JUDGES AND PROSECUTORS - SELECTED ISSUES (CONTRIBUTION TO THE DISCUSSION)}

Summary

The article analyzes the issue of competent court in the scope of protecting claims arising from employment relationships of judges and prosecutors. In the nominative employment relations of these subjects, the public law elements prevail significantly over the employee elements. The author attempts to define the concept of a case for claims arising from employment relations of this kind. The main aim of the paper is to show, based on selected examples from the current regulations, that the legislator does not perceive the complexity and specificity of the employee's service employment, which results in negative implications for the realization of the constitutional principle of the right to a court.

Keywords: judge, prosecutor, appointment, service relationship, President of the Republic of Poland, Prosecutor General

\section{BIBLIOGRAFIA}

Baran E., Baran K.W., Droga sądowa z zakresu prawa pracy osób zatrudnionych w powszechnych jednostkach organizacyjnych prokuratury, „Prokuratura i Prawo” 1995, nr 6.

Czarny P., Realizacja konstytucyjnych kompetencji Prezydenta RP w odniesieniu do sądów i Krajowej Rady Sąownictwa, [w:] System rządów Rzeczypospolitej Polskiej. Założenia konstytucyjne a praktyka ustrojowa, red. M. Grzybowski, Warszawa 2006.

Czeszejko-Sochacki Z., Prawo do sądu w świetle Konstytucji Rzeczypospolitej Polskiej (ogólna charakterystyka), „Państwo i Prawo” 1997, nr 11-12. 
Dąbrowski S., Łazarska A., [w:] Prawo o ustroju sądów powszechnych. Komentarz, red. A. Górski, LEX 2013.

Ereciński T., Gudowski J., Iwulski J., Prawo o ustroju sądów powszechnych. Ustawa o Krajowej Radzie Sadownictwa. Komentarz, Warszawa 2009.

Kijowski A., Odrębność statusu prawnego sędziów Sądu Najwyższego, „Przegląd Sądowy” 2004, nr 1.

Kiełtyka A., Kotowski W., Ważny A., Prawo o prokuraturze. Komentarz, Warszawa 2017.

Kubiak A., Konstytucyjna zasada prawa do sądu w świetle orzecznictwa Trybunału Konstytucyjnego, Łódź 2006.

Kuczyński T., [w:] M. Masternak-Kubiak, T. Kuczyński, Prawo o ustroju sqdów administracyjnych. Komentarz, Warszawa 2009.

Kuczyński T., Glosa do uchwały SN z 27 września 2002 r., III UZP 5/02, „Orzecznictwo Sądów Polskich" 2004, nr 9.

Kuczyński T., Właściwość sądu administracyjnego w sprawach stosunków stużbowych, Wrocław 2000.

Masternak-Kubiak M., [w:] Konstytucja Rzeczypospolitej Polskiej. Komentarz, red. M. Haczkowska, Warszawa 2014.

Naleziński B., [w:] Konstytucja Rzeczypospolitej Polskiej. Komentarz, red. P. Tuleja, Warszawa 2019.

Rycak A., [w:] Kodeks pracy. Komentarz, red. K. Walczak, Legalis 2020.

Sanetra W., Sąd właściwy w rozumieniu Konstytucji RP, „Przegląd Sądowy” 2011, nr 9.

Suwaj R., Glosa do postanowienia WSA w Warszawie z dnia 23 stycznia 2008 r., I Sa/wa 2139/07, „Gdańskie Studia Prawnicze - Przegląd Orzecznictwa” 2009, nr 2.

Szustakiewicz P., Stosunki stużbowe funkcjonariuszy stużb mundurowych i żotnierzy zawodowych jako sprawa administracyjna, Warszawa 2012.

Tuleja P., [w:] Konstytucja Rzeczypospolitej Polskiej. Komentarz, red. P. Tuleja, Warszawa 2019.

Wilczyńska A., Sprawa z zakresu administracji publicznej na tle pojęć sprawy administracyjnej i sprawy cywilnej — zagadnienia teoretycznoprawne, „Zeszyty Naukowe Sądownictwa Administracyjnego" 2008, nr 5.

Wyrzykowski M., Komentarz do art. 1 przepisów utrzymanych w mocy, [w:] Komentarz do Konstytucji Rzeczypospolitej Polskiej, red. L. Garlicki, Warszawa 1995-1998.

Zimmermann J., Z podstawowych zagadnień sądownictwa administracyjnego, [w:] Sadownictwo administracyjne gwarantem wolności i praw obywatelskich 1980-2005, Warszawa 2005. 
Przegląd Prawa i Administracji 124, 2021

(C) for this edition by CNS 